\title{
COVID-19 AFTERMATH AND TOURISM INNOVATION IN WESTERN BALKANS: A COMMENTARY
}

\section{INTRODUCTION}

This commentary discusses the current tourism conditions in Western Balkans (WB) and stresses the need for innovation and action-research to foster greener, more resilient and regional tourism in WB.

"We will live in a 'new-normal' tourism world - and it is our task to understand and explain it right now," state Zenker and Kock (2020, p. 3) in their call for a new tourism research agenda. They have sketched six paths that constitute a starting point for a research agenda (beyond crisis-induced research areas) which are: the levels of tourism complexity; a change in destination image; a change in tourism behaviour; a change in resident behaviour; a change in the tourist industry; and longer-term and indirect effects, for example regarding sustainability. The authors call for analytical and deep research for developing new theories. Zenker and

\footnotetext{
* Peter NIENTIED, Polis University, Rr. Bylis 12, Tirana - Durrës Highway, Km 5, Kashar, 1051, Tirana, Albania; e-mail: nientied1@chello.nl, ORCID: https://orcid.org/0000-0002-4067-9826

** Dritan SHUTINA, Co-PLAN Institute for Habitat Development, Rr: Bylis, 12, Kashar, Tirana, Albania; e-mail: dritan_shutina@co-plan.org, ORCID: https://orcid.org/0000-0003-2989-0310 
Kock's (2020) article adds to the recent review of innovation research in tourism, made before the outbreak of COVID-19 (Pikkemaat et al., 2019). However, one could question how deep this research could possibly be, given the highly uncertain current 'post-pandemic' conditions (and it even is uncertain whether one can say that the situation is 'post-pandemic'). The proposed agenda is quite challenging, yet one key topic should be added and it ought to receive priority, namely action-orientated innovation research.

COVID-19 has had major impacts on all economic sectors in WB. Tourism and hospitality have been affected particularly seriously. The pandemic has been an exceptional occurrence, because never in past decades was the whole tourism sector at a global level so seriously affected. The 9/11 attacks in the US had a global impact, it triggered a temporary decline in global tourism and required increased safety measures (Lee et al., 2005). Since the turn of the century, tourism has been exposed to health crises like SARS (severe acute respiratory syndrome, 2003) and MERS (Middle East Respiratory Syndrome, 2015). Their impact was regional hardly affecting global tourism (Gössling, Scott, and Hall, 2020). That renders earlier research on health crises in tourism relatively less relevant as they refer to certain destination regions in a world with many alternatives. The COVID-19 occurrence is a health crisis of unknown duration (vaccines help, national policies differ, and new mutations develop) that also leads to economic, social, and political issues. For tourism, 2020 was a lost season; UNWTO's World Tourism Barometer showed a $72 \%$ fall of international tourist arrivals over the period January-October 2020. In the summer of 2021 tourism figures increased again but the uncertainty about the 'new normal' in the tourism sector is high (OECD, 2020). We use the term 'new normal' for new patterns of tourist preferences, tourist industry responses, and government actions.

WB tourism is an important sector, especially in Montenegro and Albania, where in 2019 tourism contributed an estimated 22\% and 15\% to GDP, respectively (UNWTO, 2020). In the other WB countries (Bosnia Herzegovina, Kosovo, Serbia, and North Macedonia) tourism is less significant, but these countries also have tourism growth ambitions. The World Bank and the OECD (2018) have indicated the need for tourism with higher added value and stress improvement rather than innovation. Higher quality tourism implies standard recipes of better infrastructure, measures to prolong the short summer season, and improved hospitality skills. This vision is based on conventional tourism quality standards which Göler (2018) criticised; WB tourism has grown so far despite an 'imperfect' tourism product. The problem with universal recipes for enhanced tourism quality is that they point to tourism for specific target groups, based on tourism as it is. If universal quality standards are followed, that entails the risk of McDonaldisation (Ritzer, 2013) of tourism destinations, and thereby reduced authenticity of WB character and hence reduced attractiveness. 


\section{CREATIVE DESTRUCTION IN WB TOURISM?}

At first glance, the 'new normal' economic reality has parallels with what Schumpeter $(1942)^{1}$ described as a milieu for creative destruction. Creative destruction refers to the incessant product and process innovation mechanism by which new production units replace outdated or economically weak ones (Caballero, 2008). Economic crises can reshape the innovation landscape. On the one hand, firms investing in innovation are the most dynamic firms with innovation capabilities and are likely to survive a crisis. On the other, firms not involved in innovation before the crisis cannot survive without changing products and services, but a question is whether they can afford the required financial and human resources.

When translated to present-day WB tourism this means that tourism providers will go bankrupt and after this market shake-out a new situation for tourism innovation emerges. The losers would be tourism firms that keep on doing what they used to do. Archibugi et al. (2012) and Filippetti and Archibugi (2011) have shown that the effects of crises do not follow Schumpeter's theory; they found that the European 2008-2009 crisis resulted in a reduction in the willingness of firms to increase innovation investments but that a strong National System of Innovation helped firms retain their innovation investments. Caballero (2008) has also asserted that contrary to conventional wisdom, restructuring of industries falls rather than rises during economic contractions; a rise in liquidations during recessions is not accompanied by a contemporaneous increase in creation. Following this line of thinking for WB tourism, a process of uncreative destruction in the short term is to be expected, and the first signs can be witnessed in the real world. The results for WB are liquidations of tourism firms which are not accompanied by a contemporaneous increase in creation and innovation. In other words, the weakest companies go bankrupt, and others will try to survive, with the least possible business adjustments. They must compete in terms of prices, also because neighbouring tourism giants like Croatia, Greece, Turkey, and Italy work hard to attract tourists back, and their larger tourist sectors are in a better position to innovate.

\section{LIMITED WB TOURISM INNOVATION}

In WB, innovation has been limited because the tourism sector is very fragmented and mostly small-sized. Small-size tourism, as we know, has a negative impact on tourism innovation (Divisekera and Nguyen, 2018) because innovation skills and knowledge are minimal. Copying behaviour has been typical in the recent

\footnotetext{
${ }^{1}$ See Śledzik (2013) for an introduction to Schumpeter's views on innovation and entrepreneurship.
} 
goldrush-era of tourism, with Croatia and Greece as role models. Sectoral organisation for innovation is almost non-existent. The role of governments to foster innovation has been limited to marketing (Porfido, 2020; Ciro, 2019). Experience teaches us that in countries with national innovation systems, and government policy and regulation, firms and destinations are likely to innovate (Diviserka and Nguyen, 2019). "A modern innovation system is essential to help in the transition from a classic tourist sector based on providing simple accommodation and travel services to a more creative, sustainable tourism, based on innovative products and services of higher value added," concluded Smolivič et al. $(2018$, p. 5) for the case of Montenegro. This is relevant for the entire WB.

Nientied and Shutina (2020) have argued that WB tourism innovation should work towards a transformation based on new European priorities of greener and more sustainable tourism, that is more resilient (especially diversification, alternatives to the now dominant sun-sea-sand tourism) and more based on WB wide collaboration. A lesson from the 2008-2009 financial crisis has taught us that recovery was economically driven, and that sustainability was 'left for later'. Times have changed and now the EU and national governments are more aware of climate change and sustainability and take the Paris Agreements and later environmental laws and regulations more seriously. WB governments may not be doing that as of yet, but they cannot turn away if they want to remain competitive in tourism. Therefore, tourism innovation at various levels of firms (tourism providers), chains, tourism destinations (municipalities, regions, national), and tourism systems (the complex environment of actors) is needed. Albania started promoting agrotourism, which is a positive development, and many more such initiatives are needed. The small WB countries, with populations ranging from 0.6 million (Montenegro) to 7 million (Serbia), are not working together to start developing tourism ecosystems. Political issues still hamper more open borders and regional collaboration in tourism.

\section{APPLIED INNOVATION RESEARCH}

Recent review articles by Hjalager (2015), Gomezelj (2016), and Pikkemaat et al. (2019) discuss the state of the art of tourism innovation studies. Innovation research frequently adopts the enterprise and destination perspective. Tourism behaviour, networks and tourism systems receive far less attention.

A key point for WB tourism is that future tourism behaviour is uncertain; a key concern is to what extent tourists will adapt their behaviour and will favour greener options and search for less crowded destinations away from coastal mass tourism. However, it is possible to alter tourism behaviour. Slovenia, for example, opted for green tourism and diversification of experiences, and attracts in this way 
new types of tourists. ${ }^{2}$ A review by Marasco et al. (2018) on collaborative innovation in tourism highlighted the varied benefits associated with cooperative efforts developed at firm, network, destination, and regional levels, and stressed the need for innovation policy as a framework for tourism innovation actions.

The situation of WB tourism innovation is still unfavourable. Governmental budgets for R\&D are minimal, relationships between firms and universities are weak, innovation is often considered as a technical/IT matter, and such themes as service innovation and management innovation are practically undiscovered. WB national innovation systems are inadequate (Marinkovic and Dall, 2014; Nientied and Karafili, 2016; Matusiak and Kleibrink, 2018; OECD et al., 2019) and not geared towards tourism. Associations with the knowledge sector are minimal. Moreover, in the WB tourism sector, push factors for innovation have not been strong - tourism growth was realised anyway as WB benefitted from its newness factor. The issue of sustainability (Fayos-Solá and Cooper, 2019) has been of low concern in the WB tourism industry; for WB governments sustainability has been a nice word in tourism policy but without much practical application (Ciro, 2019). Innovation in organisational innovation (destination governance) has been unpopular, in both governmental and business circles (Nientied and Shutina, 2018). In WB, only a few tourism innovation studies were conducted (Bučar, 2017; Slivar et al., 2016; Cerović Smolović et al., 2018; Ciro et al., 2019). Innovation efforts for sustainable tourism in WB have been coming from environmentally concerned entrepreneurs and hardly from the tourism business community.

The COVID-19 aftermath now puts serious pressure on the tourism sector. Pursuing the proposed agenda of greener, more WB-wide and more resilient tourism will not depend on deep research, new theories or conceptual approaches. Applied innovation research and strengthening networks and tourism systems has higher priority. In WB, researchers have hardly been able to reach tourism stakeholders and support tourism innovation initiatives. International agencies have made attempts through small projects, but such projects are not repeated and dependent on foreign funding (Nientied and Shutina, 2020). For academics, much more engagement with stakeholders will support tourism innovation and may lead to an in-depth understanding of the present situation and identification of potential drivers for tourism innovation. In business innovation studies, action-oriented approaches are applied but not in tourism innovation. We argue that such approach could be very beneficial in WB tourism, and a very sensible activity for researchers to undertake. Our applied innovation research priorities, in which practices can be improved in a co-creation effort, include: the development of frameworks for tourism innovation with public and private sector stakeholders; experiments with destination management organisations, including community based tourism; the development of scenarios regarding changing inbound tourism and tourism behaviour in especially

${ }^{2}$ https://www.slovenia.info/en 
the EU; the development of cases showing the potential of sustainable tourism and the necessity for tourism resilience; and new marketing approaches to position WB tourism in new manners. To make knowledge accessible about the impacts of climate change, uncontrolled tourism development, and the potential of sustainable tourism to stakeholders through engagement with stakeholders (tourism providers, citizens, government, institutions) is an important task for researchers.

\section{REFERENCES}

ARCHIBUGI, D., FILIPPETTI, A. and FRENZ, M. (2012), Economic crisis and innovation: is destruction prevailing over accumulation?, London: Birkbeck College, University of London. https://doi.org/10.2139/ssrn.2001486

BUČAR, K. (2017), 'Green Orientation in Tourism of Western Balkan Countries', [in:] RENKO, S. and PESTEK, A. (eds.), Green Economy in the Western Balkans, Bingly: Emerald Publishing, pp. 175-209. https://doi.org/10.1108/978-1-78714-499-620171006

CABALlERO, R. J. (2008), 'Creative destruction', [in:] DURLAUF, S. N. and BLUME, L. E. (eds.), The New Palgrave Dictionary of Economics, London: Palgrave McMillan (Springer online version). https://link.springer.com/chapter/10.1057/9780230280823_5

CEROVIĆ SMOLOVIĆ, J., JANKETIĆ, S., JAĆIMOVIĆ, D., BUČAR, M. and STARE, M. (2018), 'Montenegro's road to sustainable tourism growth and innovation', Sustainability, 10, 4687. https://doi.org/10.3390/su10124687

CIRO, A. (2019), 'Tourism governance in Albania - an assessment of the policy framework for the tourism sector in Albania', Annual Review of Territorial Governance in the Western Balkans, I, pp. 69-85. https://doi.org/10.32034/CP-TGWBAR-I01-06

CIRO, A., TOSKA, M. and NIENTIED, P. (2019), 'Social innovation and sustainable economic development: participatory tourism destination management', [in:] FINKA, M., JAŠŠO, M. and HUSÁR, M. (eds.), The Role of the Public Sector in Local Economic and Territorial Development - Innovation in Central, Eastern and South Eastern, Cham: Springer, pp. 173-192. https:// doi.org/10.1007/978-3-319-93575-1_10

DIVISEKERA, S. and NGUYEN, K. (2018), 'Determinants of innovation in tourism evidence from Australia’, Tourism Management, 67, pp. 157-167. https://doi.org/10.1016/j.tourman.2018.01.010

EDUARDO FAYOS-SOLÀ, E. and COOPER, C. (eds.), (2019), The future of tourism, innovation and sustainability, Cham: Springer Nature. https://doi.org/10.1007/978-3-319-89941-1

FILIPPETTI, A. and ARCHIBUGI, D. (2011), 'Innovation in times of crisis: national system of innovation, structure and demand', Research Policy, 40, pp. 179-192. https://doi.org/10.1016/j. respol.2010.09.001

GOMEZELJ, D. O. (2016), 'A systematic review of research on innovation in hospitality and tourism', International Journal of Contemporary Hospitality Management, 28 (3), pp. 516-558. https://doi.org/10.1108/IJCHM-10-2014-0510

GÖLER, D. (2018), 'Tourism and Transition in the Western Balkans, Albania as a Laboratory for Tourism Development', Südosteuropa Mitteilungen, 4, pp. 88-98. https://fis.uni-bamberg.de/ handle/uniba/45868

GÖSSLING, S., SCOTT, D. and HALL, C. M. (2020), 'Pandemics, tourism and global change: a rapid assessment of COVID-19', Journal of Sustainable Tourism, 29 (1), pp. 1-20. https://doi. org/10.1080/09669582.2020.1758708

HJALAGER, A.-M. (2015), '100 innovations that transformed tourism', Journal of Travel Research, 54 (1), pp. 3-21. https://doi.org/10.1177/0047287513516390 
LEE, S., OH, C-O. and O'LEARY, J. T. (2005), 'Estimating the impact of the September 11 terrorist attacks on the US air transport passenger demand using intervention analysis', Tourism Analysis, 9 (4), pp. 355-361. https://doi.org/10.3727/108354205789807238

MARASCO, A., DE MARTINO, M., MAGNOTTI, F. and MORVILLO, A. (2018), 'Collaborative innovation in tourism and hospitality: a systematic review of the literature', International Journal of Contemporary Hospitality Management, 30 (6), pp. 2364-2395. https://doi.org/10.1108/ IJCHM-01-2018-0043

MARINKOVIC, I. and DALL, E. (eds.) (2014), R\&D and innovation in the Western Balkans, Vienna, EBC-INCO.net. http://wbc-inco.net/object/document/13962/attach/PUBLIKATION_WBCINCO web.pdf

MATUSIAK, M. and KLEIBRINK, A. (eds.) (2018), Supporting an innovation agenda for the Western Balkans: tools and methodologies, Luxembourg: Publications Office of the European Union. https://publications.jrc.ec.europa.eu/repository/handle/JRC111430

NIENTIED, P. and KARAFILI, E. (2016), 'Towards a pragmatic perspective on business innovation in Western Balkan countries: the case of Albania', International Journal of Business and Management, 11 (3), pp. 193-202. https://doi.org/10.5539/ijbm.v11n3p193

NIENTIED, P. and SHUTINA, D. (2018), 'Is ETIS a viable option for fostering sustainable tourism?', Annual Review of Territorial Governance in Albania, I, 2018, pp. 94-104. https://doi. org/10.32034/CP-TGAR-I01-07

NIENTIED, P. and SHUTINA, D. (2020), 'Tourism in transition, the post COVID-19 aftermath in the Western Balkans', Annual Review of Territorial Governance in the Western Balkans, II, pp. 46-60. https://doi.org/10.32034/CP-TGWBAR-I02-04

OECD (2019), SME Policy Index: Western Balkans and Turkey 2019: Assessing the Implementation of the Small Business Act for Europe, Paris: OECD. https://www.oecd.org/publications/smepolicy-index-western-balkans-and-turkey-2019-g2g9fa9a-en.htm

OECD (2020), Mitigating the impact of COVID-19 on tourism and supporting recovery, Paris: OECD (14 December update). https://doi.org/10.1787/47045bae-en

PIKKEMAAT, B., PETERS, M. and BICHLER, B. F. (2019), 'Innovation research in tourism: Research streams and actions for the future', Journal of Hospitality and Tourism Management, 41, pp. 184-196. https://doi.org/10.1016/j.jhtm.2019.10.007

PORFIDO, E. (2020), 'Tourism development in the Western Balkans: Towards a common policy', Annual Review of Territorial Governance in Albania, II, pp. 24-45. https://doi.org/10.32034/ CP-TGWBAR-I02-03

RITZER, G. (2004), The McDonaldization of society, Los Angeles CA: Sage (4 ${ }^{\text {th }}$ Revised New Century edition). https://books.google.nl/books/about/The_McDonaldization_of_Society.htm1 ?id=JAHhSDKSxz0C\&redir_esc $=\mathrm{y}$

SCHUMPETER, J. A. (1942), Capitalism, socialism, and democracy, New York NY: Harper \& Brothers.

SLINAR, I., BOŽIĆ, S. and BATKOVIĆ, A. (2016), 'Innovation in tourism, perception of tourism providers from Croatia and Serbia’, Review of Innovation and Competitiveness, 2 (4), pp. 37 55. https://doi.org/10.32728/ric.2016.24/3

ŚLEDZIK, K. (2013), 'Schumpeter's view on innovation and entrepreneurship.', [in:] HITTMAN, S. (ed.), Management Trends in Theory and Practice. Zilina: Faculty of Management Science and Informatics, University of Zilina \& Institute of Management, pp. 89-95. https://doi. org/10.2139/ssrn.2257783

UNWTO (2020), Compendium of Tourism Statistics, Data 2014-2018, Madrid: UNWTO. https:// www.e-unwto.org/doi/book/10.18111/9789284421459

ZENKER, S. and KOCK, F. (2020), 'The coronavirus pandemic - A critical discussion of a tourism research agenda', Tourism Management, 81, pp. 1-4. https://doi.org/10.1016/j.tourman.2020.104164 